\title{
Parental imprinting: potentially active chromatin of the repressed maternal allele of the mouse insulin-like growth factor II (Igf2) gene
}

\author{
Hiroyuki Sasaki, Peter A. Jones, ${ }^{1}$ J. Richard Chaillet, ${ }^{2}$ Anne C. Ferguson-Smith, Sheila C. Barton, \\ Wolf Reik, and M. Azim Surani \\ Department of Molecular Embryology, AFRC Institute of Animal Physiology and Genetics Research, Babraham, \\ Cambridge CB2 4AT, UK; ${ }^{2}$ Howard Hughes Medical Institute, Department of Genetics, Harvard Medical School, \\ Boston, Massachusetts 02115 USA
}

\begin{abstract}
The mouse insulin-like growth factor II (Igf) gene, which is located on distal chromosome 7 (Chr7), has been shown previously to undergo tissue-specific parental imprinting. This imprinting results in expression of Igf2 from the paternally inherited chromosome and repression of the maternally inherited allele in most tissues of the developing embryo. We are using embryos with the maternal duplication and paternal deficiency of distal Chr7 to characterize the mechanism that underlies repression of the maternal allele. We show that the chromatin of the $5^{\prime}$ region of the repressed Igf 2 allele is potentially active for transcription rather than heterochromatic. In particular, a CpG island that comprises one of the two strong promoters is unmethylated at both parental alleles, and DNase I hypersensitive sites in and around the strong promoters are consistently present on both parental chromosomes. In agreement with the chromatin state, primary transcripts from the maternal Igf2 allele have been detected at low but significant levels. These findings differ from observations in other instances of imprinting, namely, X-chromosome inactivation and transgene imprinting in mice. Although no parent-specific differences were detected in either DNA methylation or sensitivity to nucleases at these promoters, we have observed parental methylation differences in a region several kilobases upstream of the first exon. The differential activity of the parental Igf 2 alleles could be achieved through epigenetic modifications situated outside the promoters or by subtle and yet unidentified modifications at the promoters.
\end{abstract}

[Key Words: Parental imprinting; insulin-like growth factor II gene; DNA methylation; chromatin; mouse embryo]

Received March 16, 1992; revised version accepted July 16, 1992.

The concept of genomic or parental imprinting has become increasingly important in many fields of biology. In mammalian embryology, it has been well established that both a maternal and a paternal genome are vital for normal mouse development (Surani 1986; Surani et al. 1990; Solter 1988). This notion has been further supported by genetic complementation studies with uniparental disomies, which have identified several mouse autosomal regions whose activities are affected by their parental origins (Searle et al. 1989; Beechey et al. 1990; Cattanach and Beechey 1990|. Furthermore, some genetic traits in mice (Johnson 1974, 1975) and a variety of genetic disorders in man (Reik 1989; Clarke 1990; Hall 1990) show different phenotypes, depending on whether the affected allele is inherited from the father or the

${ }^{1}$ On sabbatical leave from Kenneth Norris Jr. Comprehensive Cancer Center, University of Southern California Medical School, Los Angeles, California 90033 USA. mother. Genesis of some types of tumor also appears to be influenced by the parental origin of the relevant genetic loci (Ferguson-Smith et al. 1990; Sapienza 1991).

Despite its relevance to many biological phenomena, little is known about the molecular basis of imprinting. The primary imprint must be established during gametogenesis, and the germ line-specific epigenetic imprint must persist through fertilization and subsequent rounds of DNA replication and cell division during development. However, reprogramming should be possible upon a subsequent passage through the germ line of the opposite sex. Thus, heritability, reversibility, and the ability to affect gene expression are the requirements for the mechanism of imprinting (Surani 1986; Sapienza et al. 1987; Monk 1988). Both DNA methylation and condensed chromatin, such as heterochromatin, fulfill these criteria, and their possible role in imprinting is suggested by findings associated with $\mathrm{X}$ chromosome inactivation and the imprinting of transgenes (see below).

In somatic cells of female eutherian mammals, com- 
pensation for the sex differences in dosage of X-linked genes is achieved by a random inactivation of the maternal or paternal X chromosomes. However, a preferential inactivation of the paternal $\mathrm{X}$ chromosome occurs in all cells of female marsupials (Cooper et al. 1971; Richardson et al. 1971; Sharman 1971) and in the extraembryonic tissues of developing female mice (Takagi and Sasaki 1975; West et al. 1977). Therefore, X chromosome inactivation can be affected by parental imprinting. Cytologically, the inactive state is associated with late replication and heterochromatinization. A redistribution of DNA methylation is observed in eutherian mammals at the molecular level and this is almost certainly involved in maintaining the inactive state (Monk 1986; Grant and Chapman 1988). Thus, the CpG islands, generally free of methylation (Bird 1986), are methylated on the inactive $\mathrm{X}$ while the remaining portions of these genes are often less methylated (e.g., Toniolo et al. 1984; Wolf et al. 1984; Yen et al. 1984). This inactive X-specific island methylation is seen primarily in the embryo proper, but recent reports suggest that it may also occur in the extraembryonic lineages (Lock et al. 1987; Singer-Sam et al. 1990), where inactivation is nonrandom. DNA methylation is often accompanied by decreased sensitivity of the chromatin to nucleases. Loss of DNase I hypersensitive sites has been reported for the HPRT and PGK genes (Riley et al. 1984, 1986; Yang and Caskey 1987; Lin and Chinault 1988), and accessibility to the endonuclease $M s p I$ has also been used to differentiate between active and inactive X chromatin (Wolf and Migeon 1985; Hansen et al. 1988; Antequera et al. 1989).

Another model system used to study mechanisms of imprinting has been provided by imprinted transgenes with methylation levels altered by parental origin $/ \mathrm{Had}-$ chouel et al. 1987; Reik et al. 1987, 1990; Sapienza et al. 1987; Swain et al. 1987; Chaillet et al. 1991; Sasaki et al. 1991). In some cases, transgene expression is affected along with methylation (Hadchouel et al. 1987; Swain et al. 1987). Although the relationship between transgene imprinting and endogenous imprinting is not clear, this model system has attracted much attention and has been studied in detail. One outcome is the characterization of genetic background effects due to modifier genes (McGowan et al. 1989; Sapienza et al. 1989; Allen et al. 1990; Reik et al. 1990; Surani et al. 1990; Engler et al. 1991); and based on their similarities to the phenomenon of position-effect variegation in Drosophila, the possible involvement of heterochromatinization in imprinting has been suggested (Allen et al. 1990; Sapienza 1990; Tartof and Bremer 1990; Engler et al. 1991; Singh et al. 1991). Significantly, in one reported case of an imprinted transgene, the maternal inhibition of tissue-specific expression has been shown to be accompanied by loss of a DNase I hypersensitive site (Pourcel et al. 1990).

The recent identification of endogenous imprinted mouse genes has now enabled us to examine the mechanism of parental imprinting. Two lines of evidence indicate that the mouse insulin-like growth factor II (Igf2) gene, located on the distal region of chromosome 7 (Chr7), undergoes parental imprinting. First, targeted mutagenesis experiments have shown that in heterozygous mice bearing one disrupted allele, Igf2 transcripts are detectable only when the remaining intact allele is derived from the father (DeChiara et al. 1991). Second, in mouse embryos with a maternal duplication and paternal deficiency of distal Chr7 (MatDi7), both maternal copies of Igf2 are repressed (Ferguson-Smith et al. 1991). Thus, it is assumed that only the paternal allele is expressed and the maternal allele is repressed in normal cells. Igf 2 encodes an embryonal mitogen widely expressed in embryonic and extraembryonic tissues in the mouse (Lee et al. 1990). Expression of Igf2 is driven by three promoters $(\mathrm{P} 1, \mathrm{P} 2$, and $\mathrm{P} 3)$, which generate alternate $5^{\prime}$ exons $(E 1, E 2$, and E3), each spliced onto the shared downstream exons E4-E6 (Rotwein and Hall 1990; Ikejiri et al. 1991). Assuming that the Igf2 imprinting is achieved at the level of transcription, transcription from the two stronger promoters $\mathrm{P} 2$ and $\mathrm{P} 3$ is apparently affected because the degree of repression is at least 10 fold (DeChiara et al. 1991; Ferguson-Smith et al. 1991). In the gene-targeting experiment, the neo gene driven by the endogenous $\mathrm{P} 2$, which is a typical $\mathrm{CpG}$ island, also exhibited the differential expression pattern on the disrupted chromosome (DeChiara et al. 1991). Interestingly, Igf2 imprinting is tissue specific: The maternal allele is not repressed in the choroid plexus and leptomeninges of the brain during late embryonic development (DeChiara et al. 1991).

Our experimental system for characterizing the molecular mechanism of parental imprinting utilizes MatDi7 embryos containing two repressed maternal copies of $\operatorname{Igf2,}$ which can be analyzed and compared with normal control embryos. Here, we report our initial attempts to identify epigenetic changes responsible for the maternal repression of Igf2. In light of the two possible mechanisms discussed above, we have carried out DNA methylation analysis and nuclease sensitivity studies of the maternal copy of Igf2, especially of the P2 and P3 regions. Our results clearly exclude extensive $\mathrm{CpG}$ island methylation as the mechanism being used for maternal repression. We also show evidence that the maternal Igf2 chromatin is potentially active for transcription rather than heterochromatic. In a region several kilobases upstream of E1, however, we have detected several sites differentially methylated, depending on the parental origin. On the basis of these findings, the possible molecular mechanisms that result in the parental imprinting of $I g f 2$ are discussed.

\section{Results}

\section{Experimental system}

Previous studies have shown that the differential expression of the parental alleles of Igf2 is seen at least from embryonic day 9.5 (e9.5) onward (DeChiara et al. 1991; Ferguson-Smith et al. 1991). Because MatDi7 embryos die around el6 (Searle and Beechey 1990), nucleic acids and nuclei were prepared from el3 to el5 embryos. In contrast to MatDi7 embryos, the reciprocal paternal disomies die at an unidentified earlier stage and cannot be 
obtained. Therefore, normal littermates of the MatDi7 embryos were used as controls throughout this study. Thus, comparative analyses were carried out between MatDi7 embryos harboring two repressed Igf2 alleles and control embryos carrying one active and one repressed allele. This allows us any epigenetic differences identified between the two embryo types to be attributed to the active paternal allele. Normal embryos at e13-e15 actively express the paternal copy of Igf2 in a variety of tissues, and the transcripts are readily detectable by Northern blot analysis in total RNA prepared from whole embryos (Ferguson-Smith et al. 1991). In the choroid plexus and leptomeninges of the brain, however, both parental copies are active during late gestation (DeChiara et al. 1991). Therefore, we carefully removed the head region before sample preparation for very sensitive experiments such as reverse transcriptase-polymerase chain reaction (RT-PCR).

\section{DNA methylation analysis of the promoters and the peptide-coding region}

To examine whether DNA methylation is involved in repressing the maternal Igf2 allele, the methylation status of the two BamHI fragments of 5.6 and $2.4 \mathrm{~kb}$ shown in Figure 1A was analyzed. The $5.6-\mathrm{kb}$ fragment contains the two stronger promoters $\mathrm{P} 2$ and $\mathrm{P} 3$ (hereafter called the P2-P3 region), and the $2.4-\mathrm{kb}$ fragment contains the polypeptide-coding exons. $\mathrm{P} 2$ is included in a $\mathrm{CpG}$ island, which also comprises the 5' half of E2. DNAs extracted from MatDi7 and control embryos at e15 and normal epididymal sperm were double digested with BamHI plus methylation-sensitive enzymes HpaII, SmaI, XhoI, or SalI.

Figure 2A shows such digests hybridized with probe $C$. The 5.6-kb BamHI fragment was cut into very small pieces by HpaII, and only one band of $0.4 \mathrm{~kb}$ was observed in all samples. This band was also the only one yielded by MspI digestion. Therefore, most of the HpaII sites that are detected by this probe appeared to be unmethylated. Similarly, four SmaI sites, $\mathrm{Sm} 1-\mathrm{Sm} 4$, and an $\mathrm{XhoI}$ site, $\mathrm{Xl}$, were cut to completion in all samples. The faint bands seen in the 3- to 4-kb region of the SmaI and XhoI lanes arose from a cross-hybridization of the probe (also visible in the $\mathrm{BamHI}$ lane) because their sizes were inconsistent with those expected for partial digestions. Hybridization with probe D confirmed the unmethylated state of this region (Fig. 2B). HpaII digestion yielded small fragments of 0.8 and $0.6 \mathrm{~kb}$ identical to the $M s p I$ digestion (except for the background smear due to a cross-hybridization). Enzymes Sall, SmaI, and XhoI demonstrated that sites Sa2, Sm5, and X1, respectively, were completely unmethylated. The unmethylated states of $\mathrm{Sm} 5$ and $\mathrm{Xl}$ were further evidenced by hybridization with probe $\mathrm{F}$ (Fig. $2 \mathrm{C}$ ). This probe also showed that the HpaII sites around E3 were only slightly methylated. Therefore, the P2-P3 region, including the CpG island, was strikingly unmethylated irrespective of the source of DNA. This clearly excludes the possibility of extensive $\mathrm{CpG}$ island methylation, such as that seen on the inac-

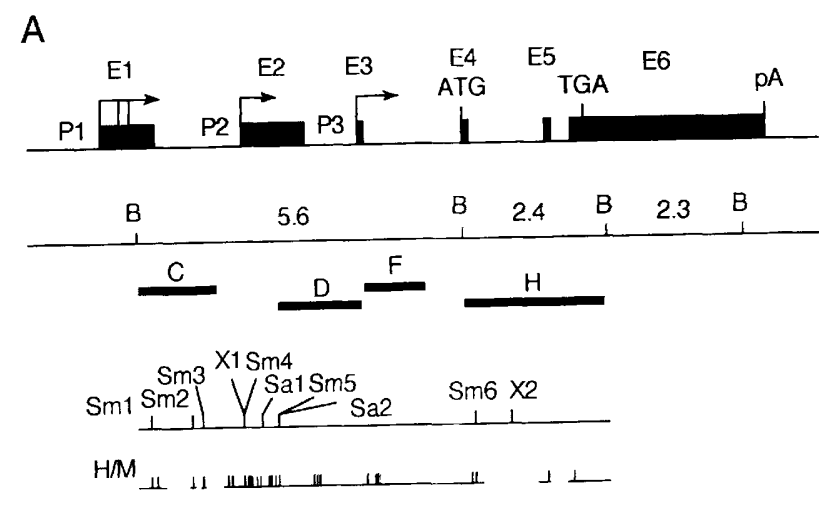

B

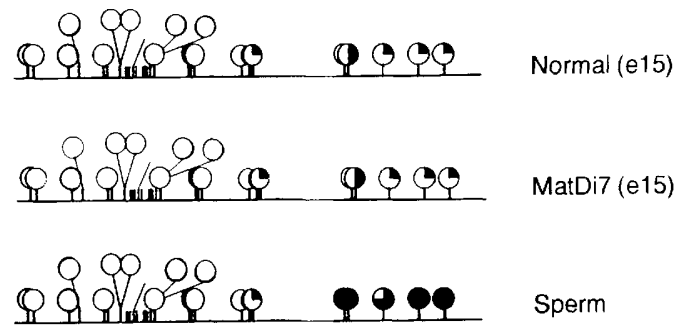

Figure 1. Overall structure and restriction map of the mouse Igf2 gene $(A)$ and summary of methylation analyses $(B) .(A)$ The positions of six exons (E1-E6; solid boxes), three promoters (P1$\mathrm{P} 3$ ), and transcription initiation sites (arrows) are indicated. ATG, TGA, and pA denote the initiation codon, termination codon, and major polyadenylation site, respectively. The BamHI sites ( $\mathrm{B}$ ) and the distances (in $\mathrm{kb}$ ) between these sites are shown. Solid lines indicate the probes used for the methylation assays: (C) BamHI-BgIII, $1.5 \mathrm{~kb}$; (D) Sall-BstEII, $1.7 \mathrm{~kb}$; $(F)$ BstEII, $1.0 \mathrm{~kb}$; $(H)$ BamHI, $2.4 \mathrm{~kb}$. The sites for methylationsensitive enzymes are SmaI $(\mathrm{Sm}) ; X$ XhoI $(\mathrm{X})$; SalI, (Sa); and HpaII-MspI (H/M). The positions of these sites are derived from the genomic sequence (Rotwein and Hall 1990), cDNA sequence (Stempien et al. 1986), and the restriction mapping experiments that we performed. The gapped portions were not determined for HpaII-MspI. (B) The methylation-sensitive enzyme sites are shown by open circles if unmethylated or a solid one if methylated. Other circles denote intermediate levels of methylation. The methylation status of sites without circles was not determined.

tive $\mathrm{X}$ chromosome, being involved in the repression of the maternal allele.

The downstream BamHI 2.4-kb region showed a somewhat different picture (Fig. 2D). Upon HpaII digestion, both MatDi7 and control DNA gave a partially methylated pattern, whereas sperm DNA gave a totally methylated pattern. Similarly, site Sm6 was partially cut in MatDi7 and control embryos but remained uncut in sperm. Site X2 was partially methylated in all cases but clearly more methylated in the sperm DNA. Thus, the methylation level of this region was higher in epididymal sperm than in e15 embryos. However, again, no difference was found between MatDi7 and normal embryos. The results obtained from all of these experiments are summarized in Figure 1B. 
A

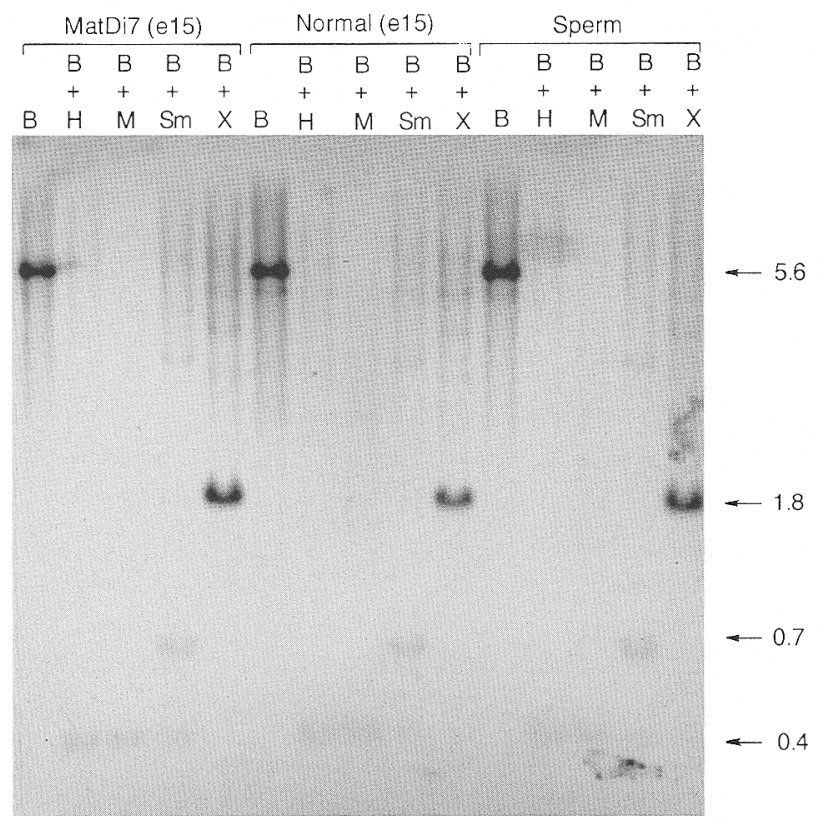

$B$

\begin{tabular}{|c|c|c|c|c|c|c|c|c|c|c|c|c|c|c|c|c|}
\hline \multicolumn{5}{|c|}{ MatDi7 (e15) } & \multicolumn{6}{|c|}{ Normal (e15) } & \multicolumn{6}{|c|}{ Sperm } \\
\hline & $B$ & $B$ & B & $B$ & $B$ & $B$ & $B$ & $B$ & $B$ & $B$ & & $B$ & $B$ & B & $R$ & $3^{\prime}$ \\
\hline & + & + & + & + & + & + & + & + & + & + & & + & + & + & + & + \\
\hline$B$ & $H$ & $M$ & $\mathrm{Sa}$ & $\mathrm{Sm}$ & $\times B$ & $H$ & $M$ & $\mathrm{Sa}$ & $\mathrm{Sm}$ & $x$ & $\mathrm{~B}$ & $\mathrm{H}$ & M & $\mathrm{Sa}$ & Sm & $x$ \\
\hline
\end{tabular}

$\mathrm{C}$

\begin{tabular}{|c|c|c|c|c|c|c|c|c|c|c|c|c|c|}
\hline \multicolumn{4}{|c|}{ MatDi7 (e15) } & \multicolumn{5}{|c|}{ Normal (e15) } & \multicolumn{5}{|c|}{ Sperm } \\
\hline & B & B B & $B$ & & $B$ & B & $B$ & $B$ & & $B$ & $\mathrm{~B}$ & $B$ & B \\
\hline & + & + & + & & + & + & + & + & & + & + & + & + \\
\hline B & $\mathrm{H}$ & $\mathrm{M} \mathrm{Sm}$ & $x$ & B & $\mathrm{H}$ & $M$ & $\mathrm{Sm}$ & $x$ & $\mathrm{~B}$ & $\mathrm{H}$ & $M$ & $\mathrm{Sm}$ & $x$ \\
\hline
\end{tabular}

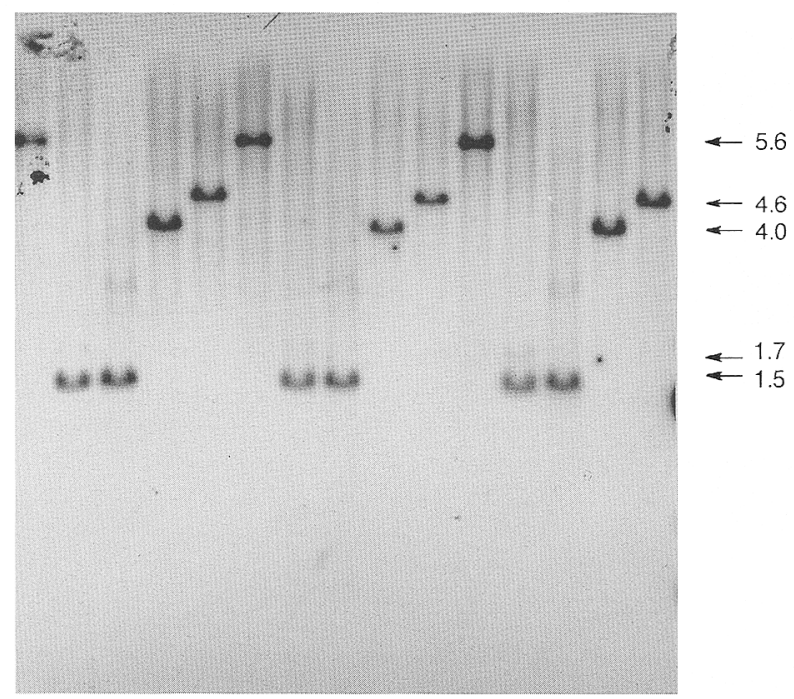

D Probe $H$

\begin{tabular}{|c|c|c|c|c|c|c|c|c|c|c|c|c|c|}
\hline & \multicolumn{4}{|c|}{ MatDi7 (e15) } & \multicolumn{4}{|c|}{ Normal (e15) } & \multicolumn{5}{|c|}{ Sperm } \\
\hline & B & B & $B$ & $B$ & B & $\mathrm{B}$ & $B$ & $\vec{B}$ & & & B & $B$ & B \\
\hline & + & + & + & + & + & + & + & + & & + & + & + & + \\
\hline & $H$ & $M$ & $\mathrm{Sm}$ & $x$ & $H$ & $M$ & $\mathrm{Sm}$ & $x$ & B & $\mathrm{H}$ & M & $\mathrm{Sm}$ & $x$ \\
\hline
\end{tabular}

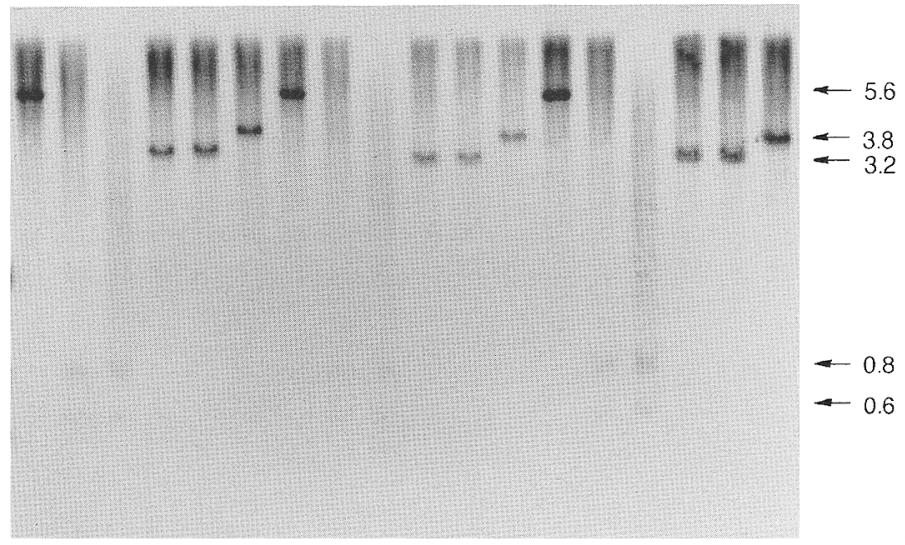

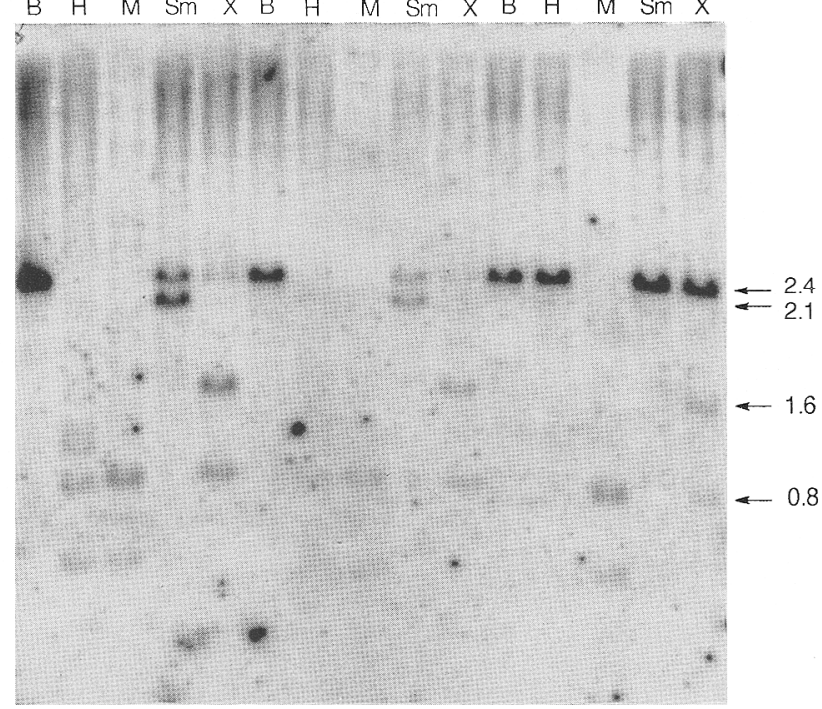

Figure 2. Autoradiographs showing the methylation status of the Igf2 gene in $\mathrm{MatDi} 7$ and control embryos at el5 and sperm from adult epididymis. DNA was digested with BamHI only or double digested with BamHI plus either HpaII (H), Mspl (M), SmaI (Sm), SalI $(\mathrm{Sa})$, or $\mathrm{XhoI}(\mathrm{X})$. The digests were hybridized to probe $\mathrm{C}(A), \mathrm{D}(B), \mathrm{F}(C)$, or $\mathrm{H}(D)$. Fragment sizes are in $\mathrm{kb}$.

\section{MspI sensitivity of the promoter regions in nuclei}

Elsewhere we show by RNA analysis that the Igf2 imprint is maintained in cultured cells derived from MatDi7 embryos (P.A. Jones et al., in prep.). In both MatDi7 and control cells, the CpG island region described above was found to remain unmethylated. It was also found that the same region was significantly methylated in the established $\mathrm{C} 3 \mathrm{H} 10 \mathrm{~T} 1 / 2 \mathrm{Cl} 8(10 \mathrm{~T} 1 / 2)$ and its transformed derivative $\mathrm{MCA} \mathrm{Cl} 15 \mathrm{Cl}$ (MCA) cell line (Reznikoff et al. 1973a,b). Various sites within this region were partially methylated in $10 \mathrm{~T} 1 / 2$ cells and heavily methylated in MCA cells. Using these cells, we then addressed the question of whether the chromatin struc- 
ture of the repressed allele differed from that of the active allele. Nuclei isolated from the cultured cells were digested with various concentrations of $M s p \mathrm{I}$, and DNA was then purified and restricted with BamHI. The samples were analyzed by Southern blotting using probe C.

As shown in Figure 3, the P2-P3 region was highly sensitive to MspI in both MatDi7 and control chromatin because the BamHI 5.6-kb band disappeared even at the lowest concentration of the enzyme. There was little difference between the two digestion profiles. In contrast, this region was highly resistant to $M s p$ I cleavage in MCA nuclei. The nuclei from $10 \mathrm{~T} 1 / 2$ cells gave a pattern intermediate between the embryo-derived cells and MCA cells. Accordingly, the accessibility to MspI showed a good correlation with the observed level of methylation. Because the reaction conditions employed here were unable to distinguish MatDi7 and control chromatin, these nuclei were also digested with reduced amounts of $\mathrm{MspI}$ (final concentration, 5, 10, or $50 \mathrm{U} / \mathrm{ml}$ ). In these experiments we observed a gradual disappearance of the BamHI 5.6-kb band; but again, no difference in sensitivity was detected (not shown). The same results were obtained with nuclei isolated from el5 embryos (not shown).

\section{DNase I hypersensitivity of the promoter regions}

To further examine the chromatin structure of the P2P3 region, we then identified and compared DNase I hy-
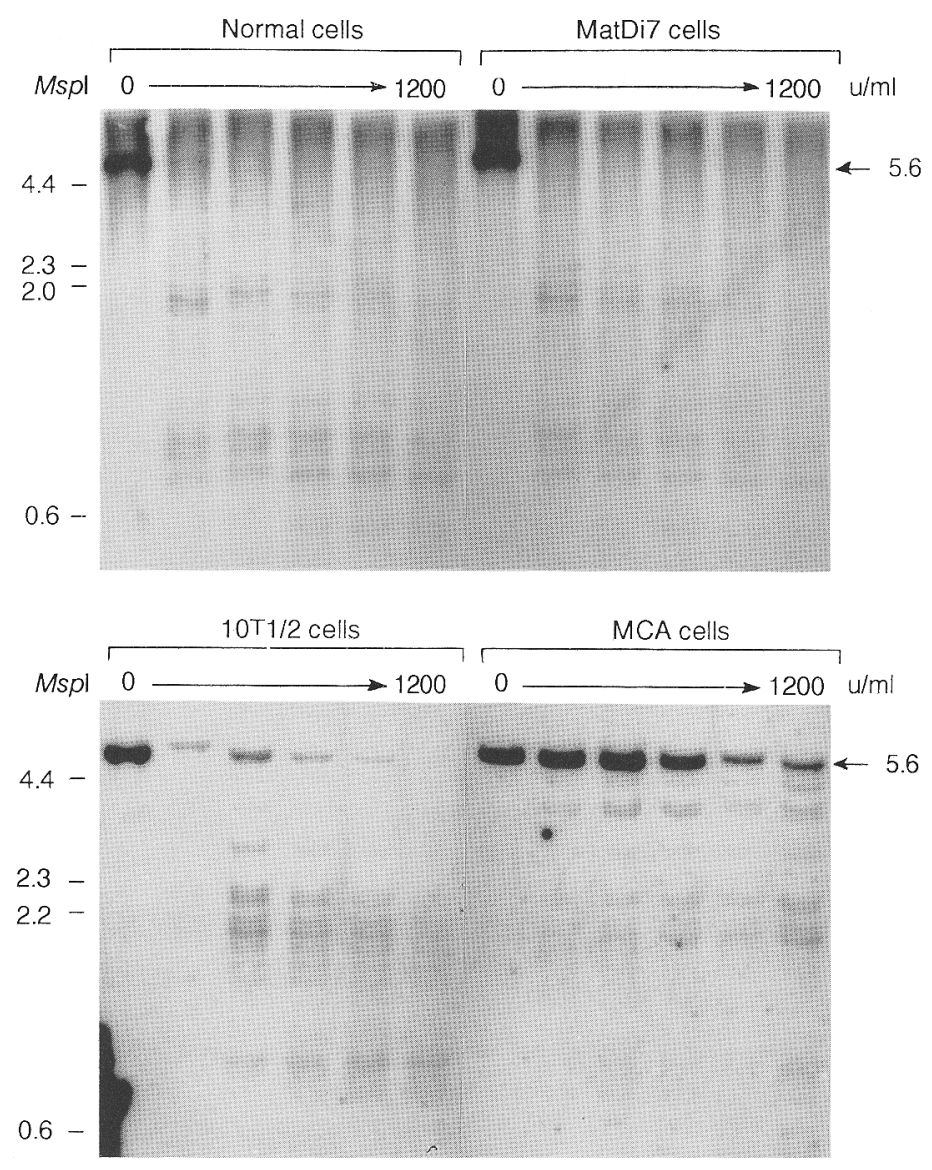

persensitive sites in MatDi7 and control embryos. Nuclei were treated with increasing concentrations of DNase I, and subsequently the purified DNA was digested with BamHI and analyzed by Southern blotting. Probes $C$ and $G$, located at the $5^{\prime}$ and $3^{\prime}$ ends of the BamHI 5.6-kb fragment, respectively, were used to map the hypersensitive sites by "indirect end-labeling" (Fig. $4 \mathrm{~A})$.

Hybridization with probe $\mathrm{C}$ revealed that both MatDi7 and control embryo nuclei at e15 contain a number of hypersensitive sites (Fig. 4B). The site giving rise to the most prominent sub-band was located within the $\mathrm{P} 2$ region of the $\mathrm{CpG}$ island (long arrow). When the same membrane was rehybridized with probe $G$, four major hypersensitive sites were clearly detected (Fig. 4C, long and medium arrows). Among these, the one in the P2 region gave the strongest signal (the long arrow), confirming the above result obtained with probe $\mathrm{C}$. The P3 region also contained one prominent hypersensitive site. The other two major sites mapped outside the promoters, but the one in the middle of E2 had also been reported in the rat gene (Evans et al. 1988). The location of these major hypersensitive sites, together with those of minor ones (short arrows), are summarized in Figure 4A.

These studies therefore showed no significant differences between the MatDi7 and control embryos. All hypersensitive sites found in normal embryos were also present in MatDi7 embryos. This result was reproducibly observed in two other experiments, one of which
Figure 3. Accessibility of the BamHI 5.6-kb (P2-P3) region of $I g f 2$ to $M s p I$ in nuclei from various cells. Nuclei were treated with increasing concentrations of $M s p I$ and analyzed by probe C. Markers are in $\mathrm{kb}$. 
A

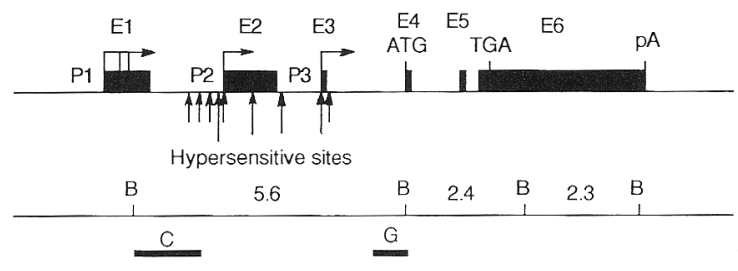

$\mathrm{C}$
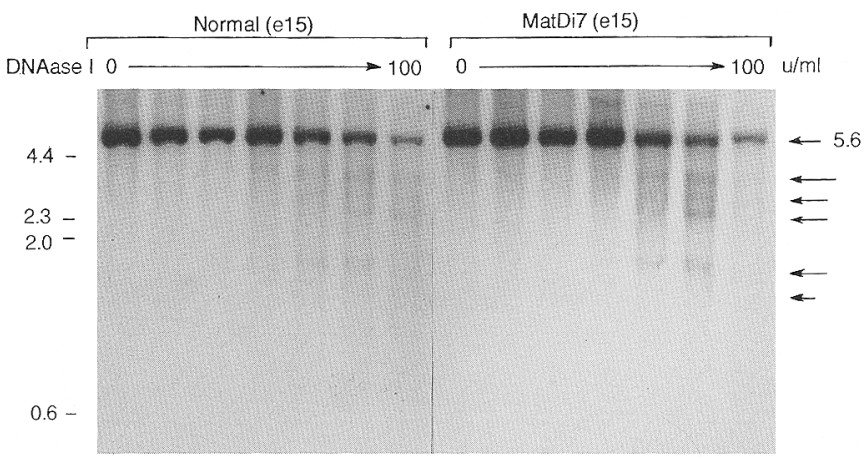

Figure 4. DNase I hypersensitivity assay of the BamHI 5.6-kb (P2-P3) region of Igf2. (A) Map of the Igf2 gene (see Fig. 1 legend) and summary of the hypersensitivity analysis. Thick solid lines (bottom) indicate the positions of the probes used for indirect end-labeling: (C) BamHI-BglII, $1.5 \mathrm{~kb}$; (G) BstEII-BamHI, $0.6 \mathrm{~kb}$. The positions of hypersensitive sites are shown by long / the most prominent site), medium (other major sites), or short (minor ones) upward arrows. (B) DNase I hypersensitive sites analyzed by probe C. Nuclei isolated from tissues and cells were digested with increasing amounts of DNase I. Sub-bands representing the hypersensitive sites are marked by long, medium or short arrows (see above). Markers are in $\mathrm{kb}$. $(C)$ Hypersensitive sites assayed by probe $\mathrm{G}$ (see above).

was done with cultured cells derived from normal and MatDi7 embryos. Slight differences in the general intensities of sub-bands were sometimes observed (e.g., compare the middle lanes in Fig. 4C), but these changes were not consistent in repeated experiments. Therefore, despite the fact that the maternal copy of Igf2 is significantly repressed at the mRNA level (DeChiara et al. 1991; Ferguson-Smith et al. 1991), it does retain DNase I hypersensitive sites.

In contrast to the above results, MCA cells, in which Igf2 is heavily methylated and not expressed, did not exhibit any hypersensitive sub-bands (Fig. 4B). This is in concordance with the observation of high resistance of MCA chromatin to MspI. Similarly, no hypersensitive sites were detected in nuclei from adult spleen (Fig. 4B), where the $\mathrm{CpG}$ island remains unmethylated but Igf2 transcripts cannot be detected (H. Sasaki et al., unpubl.). These observations indicate that under certain conditions, either in established cells or adult tissues, the P2-P3 region is no longer hypersensitive to DNase I and suggest that the Igf2 gene can exist in several chromatin states.

\section{Low-level expression of the maternal Igf2 allele}

Our findings suggest that in embryos, the chromatin of the repressed maternal allele of Igf2 may be potentially
B
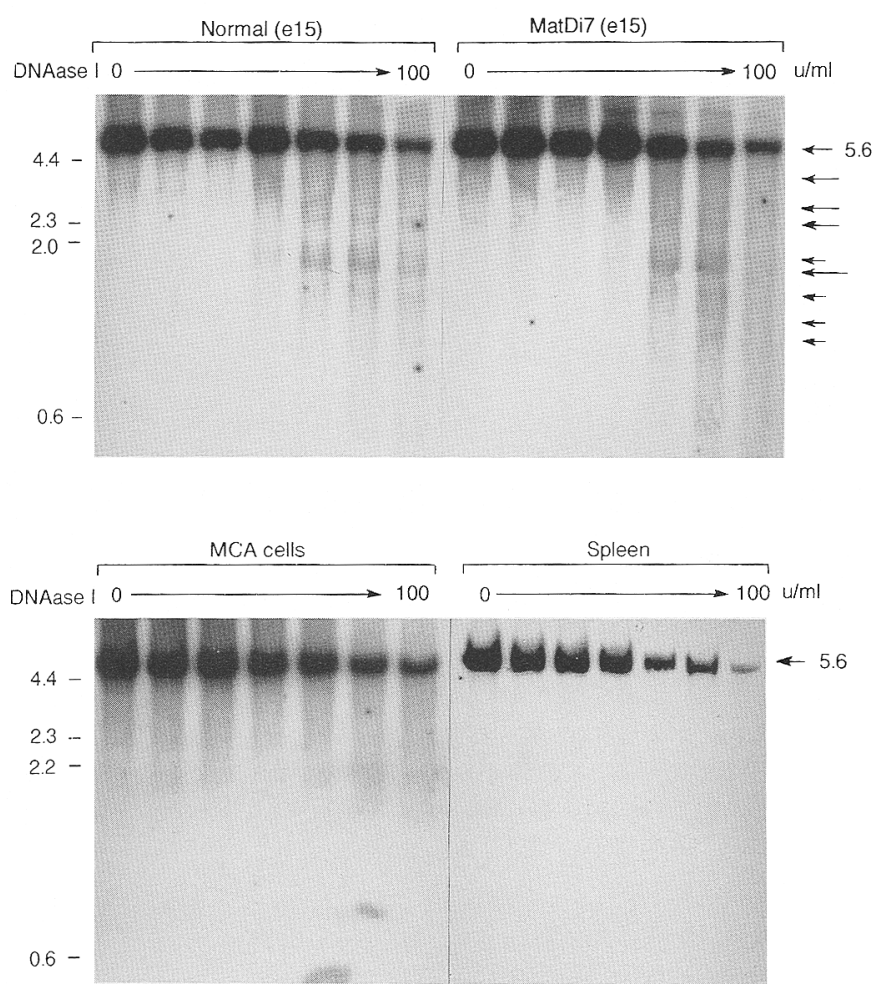

active for transcription. It is not known exactly to what degree the maternal allele is repressed. We designed a sensitive RT-PCR protocol to specifically quantitate primary transcripts initiated from all of the three promoters using sequence-specific oligonucleotide primers. The primary transcripts were assayed because large differences between the levels of primary transcripts and spliced mature mRNAs have been reported in some cases (Chang et al. 1991). Figure 5A shows the locations of the primers and probes used in this experiment. To detect primary transcripts specifically, the $5^{\prime}$ primers (OP1 and OP5) were designed to hybridize to exon sequences, and 3' primers (OP2 and OP6) to intron sequences. PCR products were identified by hybridization with probe $\mathrm{F}$ or $\mathrm{H}$ to double-check the specificity. Throughout this study, care was taken to avoid contamination with chromosomal DNA: All samples were treated with DNase I before RT reaction; and to control for successful removal, samples were split and incubated with and without RT before PCR. No amplification was observed in RT - samples, thus ruling out any contamination with chromosomal DNA (see RT - lanes, Fig. $5 \mathrm{Cl}$.

Pilot experiments with samples from normal e13 embryos were performed to determine the conditions adequate to measure relative abundance of $I g f 2$ transcripts. 
A

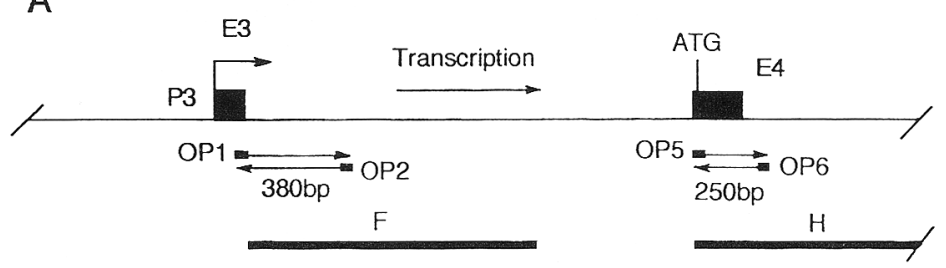

C

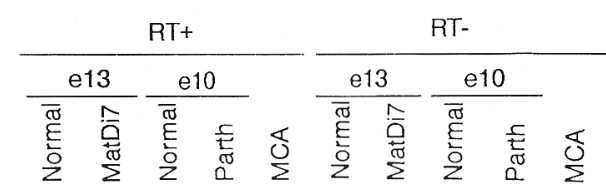
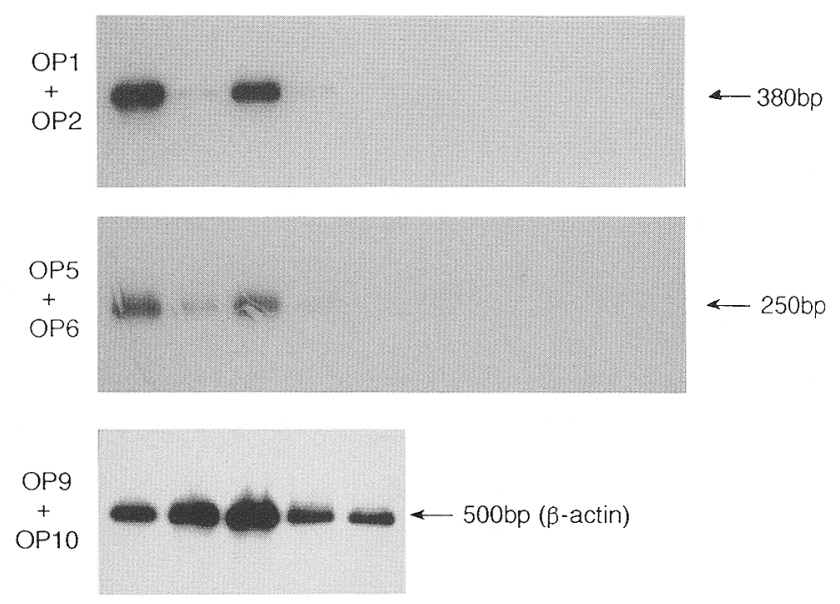

B

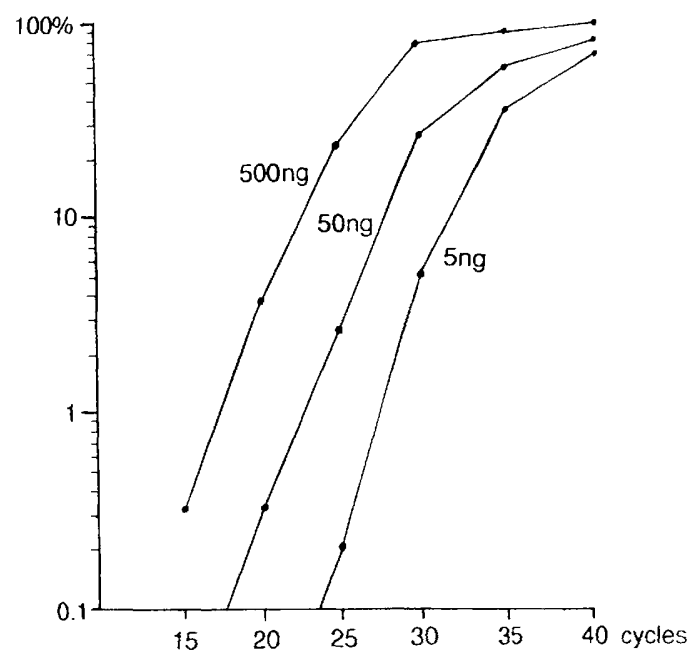

Figure 5. RT-PCR assay of the primary transcripts for Igf2. (A) Map of the Igf2 gene region corresponding to the PCR-amplified portions. The positions of the oligonucleotide primers (OP1, OP2, OP5, and OP6) are shown. Thick solid lines indicate the positions and lengths of the hybridization probes: $(F)$ BstEII, $1.0 \mathrm{~kb}$; $(H) B a m H I, 2.4 \mathrm{~kb} .(B)$ Amplification curves obtained by primers OP1 and OP2. Different amounts of nuclear RNA from normal e13 embryos were used as templates. The amount of products after 40 cycles of RT-PCR initiated with 500 ng of the template RNA is shown as $100 \%$. The proportionality of the RT-PCR products was maintained linearly up to 25 cycles. Very similar results were obtained with the other primers. (C) Autoradiographs of the Southern blots representing the results. Reverse transcription (or cDNA synthesis) was carried out with (RT + ) or without (RT -) reverse transcriptase. $\mathrm{RT}-$ lanes show the absence of DNA contamination. Transcripts for $\beta$-actin were detected by primers OP9 and OP10 and a cDNA probe. Quantitation of the PCR products was carried out by slot-blotting and densitometric scanning (see text).

The amplification reaction started with $0.5 \mu \mathrm{g}$ of the nuclear RNA proceeded in an exponential manner until 25-30 cycles of PCR and then reached the plateau phase. Therefore, we decided to use 25 cycles for quantitation. Further experiments with a series of dilutions of the same RNA sample showed that it was possible to determine the relative abundance of the Igf2 transcripts fairly precisely under the conditions that we established (Fig. 5B).

When nuclear RNAs prepared from MatDi7 or control embryos (excluding the head region) at e13 were analyzed, both primer sets detected a low but significant expression of the maternal allele (Fig. 5C). To determine the transcript levels more precisely, the PCR products were slot blotted and the hybridization signals were measured by densitometry. The results (normalized by the $\beta$-actin levels) indicated that the level of primary transcripts in MatDi7 embryos is $3.5 \%$ (OP1 + OP2) or $7.4 \%$ (OP5 + OP6) of that in controls. We then examined the Igf2 expression at an earlier el0 stage using parthenogenetic embryos instead of $\mathrm{MatDi} 7$ embryos. The parthenogenones collected for RNA preparation had variable morphology, but the majority of the embryos contained $>10$ somites. The relative level of primary transcripts in e10 parthenogenones compared with con- trols was $4.7 \%(\mathrm{OP} 1+\mathrm{OP} 2)$ or $7.5 \%$ (OP5 + OP6) (see also Fig. $5 \mathrm{C}$ ). Thus, the two maternal copies of Igf2 are repressed to very similar levels in MatDi7 and parthenogenetic embryos. In contrast, we could not detect any Igf2 transcripts in MCA cells using either of the two primer sets, although the control primers readily detected transcripts for $\beta$-actin (Fig. 5C). Therefore, it appears that the degree of repression in MCA cells is greater than the degree of repression of the maternal alleles in MatDi7 and parthenogenetic embryos. Because the relative primary transcript levels described above are for two maternal copies, the estimated activity of the maternal allele is $\sim 2-4 \%$ of that of the paternal allele.

The observed levels of transcript in MatDi7 and parthenogenones can be due to either a high level of expression in a small proportion of cells or a rather uniform low level of expression in almost all Igf2-expressing cells. The in situ hybridization data on mice with a disrupted Igf2 gene support the latter idea because the maternal allele of the intact Igf2 was active only in the choroid plexus and leptomeninges of the brain (which was excluded in our RT-PCR) (DeChiara et al. 1991). To address this question further, we have carried out in situ hybridization analysis on MatDi7 and parthenogenetic embryos. Figure 6 shows the Igf2 expression patterns in 


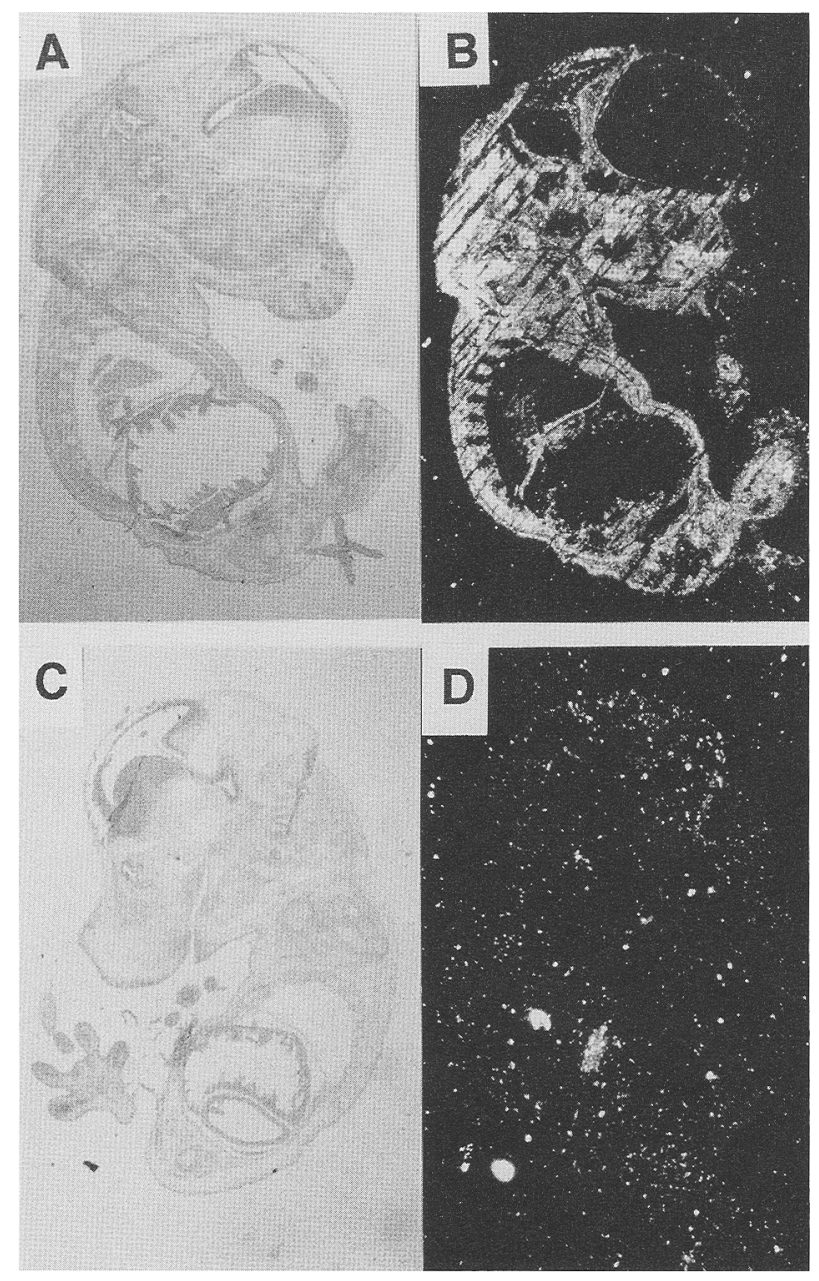

Figure 6. In situ hybridization analysis of control $(A, B)$ and MatDi7 $\{C, D\rangle$ embryos at e15. $A$ and $C$ are bright-field illumination; $C$ and $D$ are corresponding dark-field illumination. The control embryo $(B)$ shows widespread expression of Igf2 in many tissues. In the experimental MatDi7 embryo $(D)$, expression was undetectable except that high-power magnification revealed clear expression in the choroid plexus and leptomeninges (not shown).

MatDi7 and control embryos at el5. There was a marked difference in the levels of expression between these embryos, with greatly reduced expression in the MatDi7 embryos. Careful microscopic examination under high magnification of individual tissues did not reveal tissues with high levels of expression in MatDi7 embryos except for the leptomeninges and choroid plexus. Computer analysis of in situ grain counts for these expressing tissues, when compared with the background in nonexpressing tissues, gave values of 328 and 94 per unit area, respectively. We also examined el0 parthenogenones, but no significant Igf2 expression was detected in any cell type (not shown).

\section{Methylation differences upstream of the gene}

Because no parent-specific differences were found in ei- ther DNA methylation or sensitivity to nucleases within the P2-P3 region, we have set out to determine whether such changes exist in other parts of this genomic region. This analysis was initially carried out in interspecific hybrids between Mus domesticus and Mus spretus, in which the parental alleles are distinguishable. A double digest with DraI and HpaII of adult liver DNA hybridized with probe B, located $3 \mathrm{~kb}$ upstream of E1 (Fig. 7A), reveals a $5-\mathrm{kb}$ band in $M$. domesticus (C57BL/6J strain, B6), which is absent in $M$. spretus (Fig. 7B). This is because of a HpaII-MspI site polymorphism between the two species. Crosses were therefore performed to obtain reciprocal combinations of the two types of chromosomes in hybrid offspring. In offspring of the cross B6 (female) $\times$ spretus (male), the 5 - $\mathrm{kb}$ band is almost completely undetectable; whereas in the reciprocal cross (actually a $(\mathrm{B} 6 \times$ spretus $) \times \mathrm{B} 6$ backcross in which the spretus Chr7 was maternally inherited), this band is prominent. This observation suggests that HpaIl sites within this fragment are more methylated on the paternal chromosome.

To confirm this finding in the MatDi7 system and to get a better idea of where these sites might be located, we performed EcoRI and HpaII, and XbaI and HpaII double digests on DNA from MatDi7 and control embryos. Hybridization with probe $\mathrm{A}$ (Fig. $7 \mathrm{~A}$ ) showed that the $2.2-\mathrm{kb}$ band in the EcoRI digest and the 1.45-kb band in the $X b a I$ digest are much stronger in normal embryos than in MatDi7 embryos (Fig. 7C). Additional bands are stronger in normal embryos, for example, at $1.7 \mathrm{~kb}(E c o \mathrm{RI})$ and at $0.9 \mathrm{~kb}(X b a \mathrm{I})$. Hybridization of the same blot with probe $\mathrm{C}$ (Fig. 1) controls for the completeness of digestion (Fig. 7C). These results therefore indicate that multiple HpaII sites in this region are more methylated in normal embryos than in MatDi7 embryos, suggesting that the paternal chromosome, which has the active Igf2 allele, is more methylated. Although our preliminary experiment on DNase I sensitivity did not show signs of hypersensitive sites in this region, more detailed studies of both DNA methylation and chromatin structure are now under way. Attempts to identify epigenetic changes in other regions around the locus are also being made.

\section{Discussion}

We have analyzed the methylation status and chromatin structure of the maternal allele of Igf2, which is repressed by parental imprinting, and have found that the situation is unique in many respects when compared with the current models of imprinting. First, we have shown that methylation of the entire CpG island, such as that seen with genes on the inactive $\mathrm{X}$ chromosome of female mice, is not involved in repressing the maternal allele. Moreover, a number of methylatable sites located within the gene but outside the island did not display any signs of differential methylation. Thus, the methylation behavior of Igf2 also seems to differ from the imprinting of transgenes, where parental origin-dependent methylation differences are readily detectable at multiple sites distributed over considerable distances /several 
A
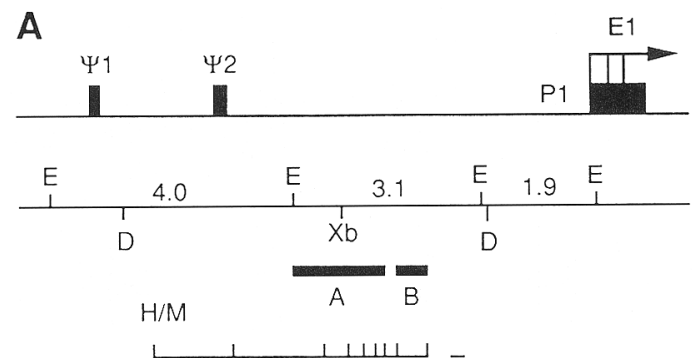

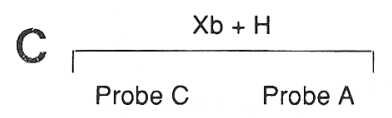

MatDi7 Normal MatDi7 Normal

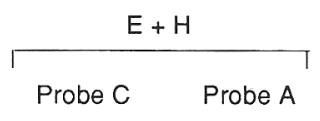

MatDi7 Normal MatDi7 Normal

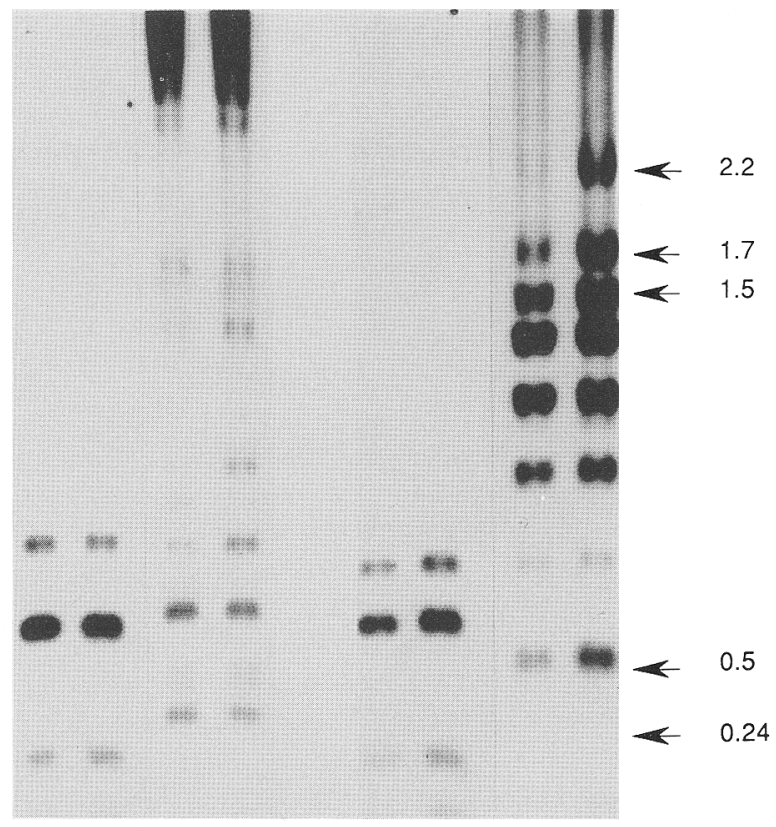

Figure 7. Differential methylation in the upstream region of the Igf2 gene. $(A)$ Map of the upstream region. Positions of E1 and two pseudoexons $\left({ }_{\Psi} 1\right.$ and $\Psi^{2}$ ) (Rotwein and Hall 1990) are shown. Restriction sites are: EcoRI (E); XbaI (Xb); DraI (D); and HpaII-MspI $(\mathrm{H} / \mathrm{M})$. Positions of enzyme sites are based on restriction mapping and sequencing by $\mathrm{R}$. Feil et al. (unpubl.). Probe $\mathrm{A}$ is a $1.5-\mathrm{kb}$ EcoRI-HindIII fragment; probe $\mathrm{B}$ is a $0.5-\mathrm{kb} M s p$ I fragment. $(B)$ Adult liver DNA from C57BL/6J, M. spretus, the $\mathrm{F}_{1}$ hybrid $(\mathrm{B} 6 \times$ spretus $\}$, and the backcross progeny $[(\mathrm{B} 6 \times$ spretus $) \times \mathrm{B} 6$, in which the presence of the maternal spretus Chr7 was verified by using the polymorphism] was double digested with $\mathrm{DraI}$ and $\mathrm{HpaII}$ and hybridized with probe B. $(C)$ DNA from MatDi7 and control fetuses was digested with $\mathrm{HpaII}$ plus either $\mathrm{XbaI}$ or EcoRI and hybridized with probe A. Control hybridization with probe $\mathrm{C}$ shows the identical digestion pattern of the two samples. Sizes are in $\mathrm{kb}$.

kb) (Hadchouel et al. 1987; Reik et al. 1987, 1990; Sapienza et al. 1987; Swain et al. 1987; Sasaki et al. 1991). Because the methylation level at most sites within the polypeptide-coding region was almost $100 \%$ in sperm but considerably less than $50 \%$ in embryos, the paternal chromosome underwent demethylation at these sites during early development. Second, the P2-P3 region of Igf2 was equally and highly accessible to $M s p I$ in maternal and paternal chromatin. The increased resistance, which we observed in the established cell lines, can be the result of the binding of methylated CpG-binding proteins caused by a higher density of methylated CpGs (Antequera et al. 1989). This is supported by the good correlation between the degree of resistance and the level of methylation in these cells. Third, both parental chromosomes exhibited a number of identical DNase I hypersensitive sites in the P2-P3 region. This is again in contrast to the cases reported for $\mathrm{X}$ chromosome inactivation (Riley et al. 1984, 1986; Yang and Caskey 1987; Lin and Chinault 1988) and the imprinting of transgenes (Pourcel et al. 1990). Because it is well established that DNase I hypersensitive sites represent nucleosome-free regions generated by the displacement of histones by activator or other DNA-binding proteins (Elgin 1988; Gross and Garrard 1988), our observations indicate that the P2-P3 region of the maternal Igf2 allele is accessible to nuclear factors and capable of forming protein-DNA complexes. Because the basis of heterochromatin is thought to be the 30-nm fiber formed by the coiling of the uninterrupted array of nucleosomes, it is unlikely that extensive heterochromatinization involving the promoters is responsible for the repression of the maternal allele.

Altogether, our results suggest that the chromatin of 
the maternal allele of $\operatorname{Igf} 2$ is in a potentially expressible or transcriptionally competent state at its promoters. We have observed a low but measurable level of expression from the maternal chromosome. The observed level (2$4 \%$ of the paternal activity) seems significant as the transcripts were not detectable when the heavily methylated and nuclease-resistant Igf2 alleles in MCA cells were examined. By comparison, a recent RT-PCR study on a human $\mathrm{X}$-linked gene, TIMP, showed that the activity of this gene is at least 100-fold less on the inactive $\mathrm{X}$ chromosome (Brown et al. 1990). Because high-level expression of the maternal Igf2 allele is restricted to the choroid plexus and leptomeninges (which were excluded in our RT-PCR), as shown by in situ hybridization, it is very likely that the observed expression represents the level of activity of the maternal allele in most Igf2-expressing cells.

Although we did not observe any global difference in either DNA methylation or nuclease sensitivity at the promoters, we cannot rule out the possibility that subtle changes, present within the examined region, were overlooked. For example, we have only examined the methylation of $\mathrm{CpG}$ sites that are testable by restriction enzymes. Also, some nuclear proteins or protein complexes that may constitute the primary imprint could be associated with either of the parental alleles in a way that does not affect nuclease sensitivity. Another possibility, which we sought in this study, is that the epigenetic modifications associated with imprinting could be present somewhere outside the promoters. We found that multiple HpaII sites located 3-4 kb upstream of E1 are more methylated on the paternal chromosome, from which the gene is expressed. This was found both by comparing MatDi7 and normal embryos, as well as in adult liver when comparing offspring from reciprocal interspecific crosses. It is interesting to note that the Prader-Willi/Angelman region in the human shows methylation imprinting, with some sites being more methylated on the paternal chromosome and others on the maternal chromosome (Nicholls et al. 1992). We cannot therefore exclude the possibility that there are sites elsewhere in the locus that are more methylated on the maternal chromosome. At present, we do not know whether the observed differential methylation is in any way involved in establishing or maintaining the imprint of the Igf2 gene. It will also be interesting to see whether the changes are already present in the gametes or whether they arise after fertilization.

The mechanism by which parental-specific epigenetic modifications regulate Igf2 expression continues to be a subject of speculation. However, whatever the imprint is, and wherever it exists, it should control the level of transcripts initiated from the multiple promoters. Our preliminary results from nuclear run-on experiments with MatDi7 nuclei suggest that the maternal allele is repressed at the level of transcription $(\mathrm{H}$. Sasaki et al., unpubl.). A simple explanation for the control of the multiple transcripts was initially considered to be heterochromatinization of the entire locus, but this is now unlikely, as shown in this study. Other mechanisms that can act on a domain basis, such as late replication and alteration of superhelical density by topoisomerase II, could be involved, but only if they are separable from heterochromatinization. There are a number of other possibilities, but the models described below have some attractive features and are therefore worth mentioning.

First, if transcriptional attenuation or premature termination occurs downstream of the three promoters, it will offer an efficient way of blocking all transcription. There is growing evidence that this type of regulation is important for many eukaryotic genes (for review, see Proudfoot 1989; Spencer and Groudine 1990; Kerppola and Kane 1991). In this connection, it is intriguing that antisense transcription of Igf2 has been identified in chick embryos (Taylor et al. 1991), because it could interfere with the sense transcription. The second possibility, promoter occlusion, is another type of transcriptional interference, which down-regulates transcription at the initiation step (Proudfoot 1986; Corbin and Maniatis 1989). The effect is caused by transcription from an upstream promoter and could affect multiple downstream promoters. It is known that the insulin-2 (Ins-2) gene is $\sim 17 \mathrm{~kb}$ upstream of Igf2 (Rotwein and Hall 1990), but a systematic search for intergenic transcription has not been carried out in the mouse. The attenuation model and the promoter occlusion model are testable by detailed run-on transcription experiments. The third model assumes the presence of enhancers or silencers associated with Igf2. Epigenetic modifications might down-regulate transcription by controlling some of these distantly situated elements without affecting the basic activities of the promoters. Although none of these elements has been identified for Igf2, this model becomes particularly attractive if we consider the existence of the $H 19$ gene in close proximity to Igf2, as it has an enhancer in its $3^{\prime}$-flanking region (Yoo-Warren et al. 1988). The temporal and spatial distribution of $H 19$ expression during mouse development is similar to that of Igf2 (Poirier et al. 1991). Moreover, this gene is imprinted in the opposite direction to Igf2- the maternal allele being active and the paternal allele repressed (Bartolomei et al. 1991). The H19 enhancer consists of at least two separable enhancer elements (Yoo-Warren et al. 1988) and thus has the potential to interact with multiple promoters. Therefore, it is tempting to speculate that the H19 enhancer interacts specifically with the $H 19$ promoter on the maternal chromosome and with the Igf2 promoters on the paternal chromosome. The original model of promoter competition for an enhancer has been proposed for the developmental switching of the $\beta$-globin genes (Choi and Engel 1988). Parental origin-specific interaction between the common enhancer and the two genes could be achieved through the action of negative regulatory elements that block specific enhancer-promoter interactions. Sequence elements that inhibit enhancer activity have been identified in several mammalian genes and are called repressors (Vacher and Tilghman 1990), silencers (Nakabayashi et al. 1991), or sequestering elements (Stauffer and Ciejek-Baez 1992). The parental methylation differences that we have observed in the upstream 
region could play a role in these models, especially in those involving remote regulatory signals.

\section{Materials and methods}

Animals and cells

Mice used to produce MatDi7 embryos were kindly supplied by B. M. Cattanach and C. V. Beechey (MRC Radiobiology Unit, Oxford, UK). The MatDi7 embryos were obtained from the $\mathrm{T} 9 \mathrm{H} d /+c$ (female) $\times \mathrm{T} 9 \mathrm{H}+/++($ male $)$ intercrosses at the expected frequency of $\sim 17 \%$ (Searle and Beechey 1990). A lack of eye pigment owing to the two maternal $c$ alleles allowed us to distinguish the MatDi7 embryos from littermates. Parthenogenetic embryos were produced from unfertilized (C57BL/ $6 \mathrm{~J} \times \mathrm{CBA} / \mathrm{Ca}) \mathrm{F}_{1}$ eggs by the method described previously $(\mathrm{Su}-$ rani et al. 1988). After cytochalasin-B treatment, the parthenogenetic eggs containing two pronuclei were cultured for an additional 2 days and then transferred to the oviducts of day- 1 pseudopregnant $F_{1}$ recipients. The derivation and characterization of cells from the MatDi7 embryos and their littermates will be described elsewhere (P.A. Jones et al., in prep.).

\section{Isolation of nuclei}

Whole embryos, portions of embryo and adult spleen were homogenized manually in $5 \mathrm{ml}$ of nuclear buffer $[60 \mathrm{mM} \mathrm{KCl}, 15$ $\mathrm{mm} \mathrm{NaCl}, 5 \mathrm{~mm} \mathrm{MgCl}, 0.1 \mathrm{~mm}$ EGTA, $15 \mathrm{~mm}$ Tris- $\mathrm{HCl}(\mathrm{pH}$ 7.4), $0.5 \mathrm{~mm}$ dithiothreitol (DTT), $0.1 \mathrm{~mm}$ phenylmethylsulfonyl fluoride (PMSF)] (Wu 1989) containing $0.3 \mathrm{M}$ sucrose (nuclear buffer $/ 0.3 \mathrm{M}$ sucrose). In some experiments, $0.2 \mathrm{~mm}$ spermine and $0.5 \mathrm{~mm}$ spermidine were added. The homogenate was filtered through a pad of cheesecloth, layered over a 4-ml cushion of nuclear buffer/ $1.2 \mathrm{M}$ sucrose, and centrifuged at $8000 \mathrm{rpm}$ for $20 \mathrm{~min}$. Pelletted nuclei were resuspended in a small volume of nuclear buffer $/ 0.3 \mathrm{M}$ sucrose $/ 5 \%$ glycerol and stored at $-80^{\circ} \mathrm{C}$. To obtain nuclei from cultured cells, cells were first washed with phosphate-buffered saline in $100-\mathrm{mm}$ dishes and then allowed to lyse in $1 \mathrm{ml} /$ dish of a cold solution composed of $5 \mathrm{~mm} \mathrm{MgCl} 2,10 \mathrm{~mm}$ Tris- $\mathrm{HCl}(\mathrm{pH} 8.0), 1 \%$ Triton X-100, 0.5 mM DTT, 0.1 mM PMSF, $0.32 \mathrm{M}$ sucrose. Crude nuclei were collected by centrifugation at $4000 \mathrm{rpm}$ for $20 \mathrm{~min}$. Samples were resuspended and stored as described above.

\section{Nuclease digestion of nuclei}

For MspI digestion, nuclei equivalent to $10 \mu \mathrm{g}$ of DNA were resuspended in $90 \mu \mathrm{l}$ of $10 \mathrm{mM} \mathrm{KCl}, 10 \mathrm{~mm}$ Tris- $\mathrm{HCl}$ (pH 7.7), 10 $\mathrm{mM} \mathrm{MgCl}_{2}$, and $10 \mathrm{~mm} \beta$-mercaptoethanol. The samples were combined with $10 \mu \mathrm{l}$ of the same solution containing $0.75,1.5$, 3, 6, or $12 \mathrm{U} / \mu \mathrm{l}$ of $\mathrm{MspI}$ (Stratagene) (final concentration, 75, $150,300,600$, or $1200 \mathrm{U} / \mathrm{ml}$, respectively) and digested at $37^{\circ} \mathrm{C}$ for $30 \mathrm{~min}$. DNase I digestions were carried out with nuclei equivalent to $20 \mu \mathrm{g}$ of DNA in $90 \mu \mathrm{l}$ of nuclear buffer $/ 0.3 \mathrm{M}$ sucrose $/ 5 \%$ glycerol. After the addition of $10 \mu \mathrm{l}$ of the same solution containing $0.03,0.06,0.125,0.25,0.5$, or $1 \mathrm{U} / \mu \mathrm{l}$ of DNase I (Pharmacia) (final concentration, 3, 6, 12.5, 25, 50, or $100 \mathrm{U} / \mathrm{ml}$, respectively), the samples were digested at $25^{\circ} \mathrm{C}$ for $5 \mathrm{~min}$. These reactions were terminated by adding an equal volume of $20 \mathrm{~mm}$ EDTA ( $\mathrm{pH} 8.0$ ), $1 \%$ SDS containing $0.5 \mathrm{mg} / \mathrm{ml}$ of proteinase $\mathrm{K}$. Proteinase $\mathrm{K}$ digestion was carried out overnight at $37^{\circ} \mathrm{C}$. DNA was purified by phenol-chloroform extraction, followed by ethanol precipitation, and then subjected to Southern blot analysis.

\section{$R T-P C R$}

Nuclear RNA was isolated from the nuclei preparations by the method of Chirgwin et al. (1979). To destroy contaminated chromosomal DNA, RNA samples $(5 \mu \mathrm{g})$ were brought into 25 $\mu l$ of $40 \mathrm{~mm}$ Tris- $\mathrm{HCl}$ (pH 7.5), $6 \mathrm{mM} \mathrm{MgCl}, 2 \mathrm{mM} \mathrm{CaCl}_{2}$, and digested with 10 units of DNase I (RNase free, Stratagene) at $37^{\circ} \mathrm{C}$ for $5 \mathrm{~min}$. RNA of $0.5 \mu \mathrm{g}$ was mixed with $2 \mu \mathrm{l}$ of $10 \times \mathrm{RT}$ buffer $[0.5 \mathrm{M}$ Tris- $\mathrm{HCl}(\mathrm{pH} 8.0), 0.75 \mathrm{M} \mathrm{KCl}, 30 \mathrm{mM} \mathrm{MgCl}, 0.1 \mathrm{M}$ DTT], $1 \mu \mathrm{l}$ of 3' primer (OP2, OP6, or OP10) (160 ng), and $2 \mu$ ] of $5 \mathrm{~mm}$ dNTPs. The final volume was adjusted to $19 \mu \mathrm{l}$ with water, and the mixture was incubated at $72^{\circ} \mathrm{C}$ for $2 \mathrm{~min}$. The sample was then split into two halves, and $0.5 \mu \mathrm{l}$ of Moloney murine RT (10 units, Stratagene) was added to one of them. The other half served as a negative control to confirm the absence of DNA contamination. Both tubes were incubated at $37^{\circ} \mathrm{C}$ for 30 min. A small portion of RT products $(2 \mu \mathrm{l})$ was mixed with 77 $\mu \mathrm{l}$ of water, $10 \mu \mathrm{l}$ of $10 \times$ PCR buffer (Cambio), $3 \mu \mathrm{l}$ of 3 ' primer (480 ng), $3 \mu \mathrm{l}$ of $5^{\prime}$ primer (480 ng), $4 \mu \mathrm{l}$ of $5 \mathrm{~mm}$ dNTPs, and 1 $\mu \mathrm{l}$ of Taq DNA polymerase ( 5 units, Cambio). The mixture was covered with a layer of mineral oil and amplified by PCR for 25 cycles. Each cycle consisted of $1 \mathrm{~min}$ at $94^{\circ} \mathrm{C}, 30 \mathrm{sec}$ at $65^{\circ} \mathrm{C}$, and 1 min at $72^{\circ} \mathrm{C}$. A portion of the PCR product $(20 \mu \mathrm{l})$ was analyzed by Southern blotting or by slot blotting. In each experiment, DNA contamination was excluded by the fact that no signal was obtained if no reverse transcriptase was added. The oligonucleotide primers used are as follows: OP1 (exon 3-intron 3, 5'), 5'-AGCGGCCTCCTTACCCAACT'TCAG-3'; OP2 lexon 3 -intron 3, 3' 1 , 5'-TGACCTCGAAGTCCCTTCCCAAAG-3'; OP5 (exon 4-intron 4, 5'), $5^{\prime}$-ATCCCAGTGGGGAAGTCGATGTTG-3'; OP6 (exon 4-intron 4, 3'), 5'-AAGGGGTAGCTTAAGAGCAAGGCC-3'; OP9 $\left(\beta\right.$-actin, $\left.5^{\prime}\right), 5^{\prime}$-GCTGTGCTATGTTGCTCTAGACTTC-3'; OP10 ( $\beta$-actin, $\left.3^{\prime}\right)$, 5'-CTCAGTAACAGTCCGCCTAGAAGC-3'.

\section{DNA blot analysis}

Genomic DNAs isolated from embryos, sperm, and nucleasedigested nuclei were cut with appropriate restriction enzymes according to the manufacturer's recommendations. Restricted DNA fragments and RT-PCR products were electrophoresed on $0.8-1.5 \%$ agarose gels, blotted onto nylon membranes (Hybond$\mathrm{N}^{+}$, Amersham), and UV-cross-linked (Stratalinker, Stratagene). A portion of RT-PCR product was also blotted by Bio-Dot SF microfiltration apparatus (Bio-Rad) for a densitometric analysis. Hybridization probes were subcloned from the cosmid clone cosIGF4 (Rotwein and Hall 1990), which was kindly provided by P. Rotwein (Washington University, St. Louis, MO), and radiolabeled by the random priming method of Feinberg and Vogelstein (1984). The membranes were hybridized with the probes in the solution described by Church and Gilbert (1984), and washing was performed in $0.1 \times \mathrm{SSC}, 0.1 \% \mathrm{SDS}$, at $65^{\circ} \mathrm{C}$. Densitometry of band intensities was done on a Chromoscan 3 (Joyce Loebl).

\section{In situ hybridization}

Preparation of embryo sections, generation of the probes, and in situ hybridization were performed as described /Ohlsson et al. 1989). The riboprobe was produced by using a plasmid clone containing a 680-bp HinfI-PstI human cDNA insert.

\section{Acknowledgments}

We thank B.M. Cattanach and C.V. Beechey for mice homozygous for the T9H translocation, R. Ohlsson and B. Keverne for in 
situ hybridization and photographs, P. Rotwein for the Igf2 cosmid clone, R. Feil for sequence information, W. Mills for technical help, N.D. Allen and K. Mooslehner for helpful discussions, and all of the other members of our laboratory for help and advice with this work. We also thank R. Kothary for participating in the initial phase of this work. H.S. is supported by fellowships from the Uehara Memorial Foundation, the Japan Society for Promotion of Sciences, and the Wellcome Trust, and A.C.F.-S. by a Babraham Research Fellowship. W.R. is a fellow of the Lister Institute of Preventive Medicine. P.A.J. was on sabbatical leave, partially supported by an Eleanor Roosevelt Fellowship from the International Union against Cancer and by research grant CA49758 from the National Institutes of Health. A portion of this work was performed in the laboratory of Philip Leder (Harvard Medical School), and was supported by a grant from E. I. Dupont de Nemours Co., Inc.

The publication costs of this article were defrayed in part by payment of page charges. This article must therefore be hereby marked "advertisement" in accordance with 18 USC section 1734 solely to indicate this fact.

\section{References}

Allen, N.D., M.L. Norris, and M.A. Surani. 1990. Epigenetic control of transgene expression and imprinting by genotypespecific modifiers. Cell 61: 853-861.

Antequera, F., D. Macleod, and A.P. Bird. 1989. Specific protection of methylated CpGs in mammalian nuclei. Cell 58: $509-517$

Bartolomei, M.S., S. Zemel, and S.M. Tilghman. 1991. Parental imprinting of the mouse H19 gene. Nature 351: 153-155.

Beechey, C.V., B.M. Cattanach, and A.G. Searle. 1990. Genetic imprinting map. Mouse Genome 87: 64-65.

Bird, A.P. 1986. CpG-rich island and the function of DNA methylation. Nature 321: 209-213.

Brown, C.J., A.M. Flenniken, B.R.G. Williams, and H.F. Willard. 1990. X chromosome inactivation of the human TIMP gene. Nucleic Acids Res. 18: 4191-4195.

Cattanach, B.M. and C.V. Beechey. 1990. Autosomal and X-chromosome imprinting. Development (Suppl.) 63-72.

Chaillet, J.R., T.F. Vogt, D.R. Beier, and P. Leder. 1991. Parentalspecific methylation of an imprinted transgene is established during gametogenesis and progressively changes during embryogenesis. Cell 66: 77-83.

Chang, C.-D., P. Phillips, K.E. Lipson, V.J. Cristofolo, and R. Baserga. 1991. Senescent human fibroblasts have a post-transcriptional block in the expression of the proliferating cell nuclear antigen gene. J. Biol. Chem. 266: 8663-8666.

Chirgwin, J.M., A.E. Przybyla, R.J. McDonald, and W.J. Rutter. 1979. Isolation of biologically active ribonucleic acid from sources enriched in ribonuclease. Biochemistry 18: 5294 5299.

Choi, O.-R.B. and J.D. Engel. 1988. Developmental regulation of $\beta$-globin gene switching. Cell 55: 17-26.

Church, G.M. and W. Gilbert. 1984. Genomic sequencing. Proc. Natl. Acad. Sci. 81: 1991-1995.

Clarke, A. 1990. Genetic imprinting in clinical genetics. Development (Suppl.) 131-136.

Cooper, D.W., J.L. VandeBerg, G.B. Sharman, and W.F. Poole. 1971. Phosphoglycerate kinase polymorphism in kangaroo provides further evidence for paternal $\mathrm{X}$ inactivation. Nat. New Biol. 230: 155-157.

Corbin, V. and T. Maniatis. 1989. Role of transcriptional interference in the Drosophila melanogaster Adh promoter switch. Nature 337: 279-282.
DeChiara, T.M., E.J. Robertson, and A. Efstratiadis. 1991. Parental imprinting of the mouse insulin-like growth factor II gene. Cell 64: 849-859.

Elgin, S.C. 1988. The formation and function of DNase I hypersensitive sites in the process of gene activation. I. Biol. Chem. 263: 19259-19262.

Engler, P., D. Haasch, C.A. Pinkert, L. Doglio, M. Glymour, R. Brinster, and U. Storb. 1991. A strain-specific modifier on mouse chromosome 4 controls the methylation of independent transgenic loci. Cell 65: 939-947.

Evans, T., T. DeChiara, and A. Efstratiadis. 1988. A promoter of the rat insulin-like growth factor II gene consists of minimal control elements. I. Mol. Biol. 199: 61-81.

Feinberg, A.P. and B. Vogelstein. 1984. A technique for radiolabeling DNA restriction endonuclease fragments to high specific activity. Anal. Biochem, 137:1266-1267.

Ferguson-Smith, A.C., W. Reik, and M.A. Surani. 1990. Genomic imprinting and cancer. Cancer Surv. 9: 487-503.

Ferguson-Smith, A.C., B.M. Cattanach, S.C. Barton, C.V. Beechey, and M.A. Surani. 1991. Embryological and molecular investigations of parental imprinting on mouse chromosome 7. Nature 351: 667-670.

Grant, S.G. and V.M. Chapman. 1988. Mechanisms of X-chromosome regulation. Annu. Rev. Genet. 22:1199-1233.

Gross, D.S. and W.T. Garrard. 1988. Nuclease hypersensitive sites in chromatin. Annu. Rev. Biochem. 57: 159-197.

Hadchouel, M., H. Farza, D. Simon, P. Tiollais, and C. Pourcel. 1987. Maternal inhibition of hepatitis B surface antigen gene expression in transgenic mice correlates with de novo methylation. Nature 329: 454-456.

Hall, J.G. 1990. Genomic imprinting: Review and relevance to human diseases. Am. I. Hum. Genet. 46: 103-123.

Hansen, R.S., N.A. Ellis, and S.M. Gartler. 1988. Demethylation of specific sites in the $5^{\prime}$ region of the inactive X-linked human phosphoglycerate kinase gene correlates with the appearance of nuclease sensitivity and gene expression. Mol. Cell. Biol. 8: 4692-4699.

Ikejiri, K., M. Furuichi, T. Ueno, T. Matsuguchi, K. Takahashi, H. Endo, and M. Yamamoto. 1991. The presence and active transcription of three independent leader exons in the mouse insulin-like growth factor II gene. Biochim. Biophys. Acta 1089: $77-82$.

Johnson, D.R. 1974. Hairpin-tail: A case of post-reductional gene action in the mouse egg. Genetics 76: 795-805.

- 1975. Further observations on the hairpin tail (Thp) mutation in the mouse. Genet. Res. 24: 207-213.

Kerppola, T.K. and C.M. Kane. 1991. RNA polymerase: Regulation of transcript elongation and termination. FASEB $\quad$. 5: 2833-2842.

Lee, J., J. Pintar, and A. Efstratiadis. 1990. Pattern of the insulinlike growth factor II gene expression during early mouse development. Development 110: 151-159.

Lin, D. and A.C. Chinault. 1988. Comparative study of DNase I sensitivity at the X-linked human HPRT locus. Somat. Cell Mol. Genet. 14: 261-272.

Lock, L.F., N. Takagi, and G.R. Martin. 1987. Methylation of the Hprt gene on the inactive $\mathrm{X}$ occurs after chromosome inactivation. Cell 48: 39-46.

McGowan, R., R. Campbell, A. Peterson, and C. Sapienza. 1989. Cellular mosaicism in the methylation and expression of hemizygous loci in the mouse. Genes $\leftrightarrow$ Dev. 3: 1669-1676.

Monk, M. 1986. Methylation and the X chromosome. BioEssays 4: 204-208.

—. 1988. Genomic imprinting. Genes \& Dev. 2: 921-925.

Nakabayashi, H., T. Hashimoto, Y. Miyano, K.-K. Tjong, J. Chan, and T. Tamaoki. 1991. A position-dependent silencer 
plays a major role in repressing $\alpha$-fetoprotein expression in human hepatoma. Mol. Cell. Biol. 11: 5885-5893.

Nicholls, R.D., E.M. Rinchik, and D.J. Driscoll. 1992. Genomic imprinting in mammalian development: Prader-Willi and Angelman syndrome as disease models. In Seminars in developmental biology (ed. M.A. Surani and W. Reik), vol. 3, pp. 139-152. Academic Press, London, UK.

Ohlsson, R., L. Holmgren, A. Glaser, A. Szpecht, and S. PfeiferOhlsson. 1989. Insulin-like growth factor 2 and short-range stimulatory loops in control of human placental growth. EMBO /. 8: 1993-1999.

Poirier, F., C.-T. J. Chan, P.M. Timmons, E.J. Robertson, M.J. Evans, and P.W.J. Rigby. 1991. The murine $H 19$ gene is activated during embryonic stem cell differentiation in vitro and at the time of implantation in the developing embryo. Development 113: 1105-1114.

Pourcel, C., P. Toillais, and H. Farza. 1990. Transcription of the $S$ gene in transgenic mice is associated with hypomethylation at specific sites and with DNase I sensitivity. J. Virol. 64: 931-935.

Proudfoot, N.J. 1986. Transcriptional interference and termination between duplicated $\alpha$-globin gene constructs suggests a novel mechanism for gene regulation. Nature 322: 562-565.

-1989. How RNA polymerase II terminates transcription in higher eukaryotes. Trends Biochem. Sci. 14: 105-110.

Reik, W. 1989. Genomic imprinting and genetic disorders in man. Trends Genet. 5: 331-336.

Reik, W., A. Collick, M.L. Norris, S.C. Barton, and M.A. Surani. 1987. Genomic imprinting determines methylation of parental alleles in transgenic mice. Nature 328: 248-251.

Reik, W., S.K. Howlett, and M.A. Surani. 1990. Imprinting by DNA methylation: From transgenes to endogenous gene sequences. Development (Suppl.) 99-106.

Reznikoff, C.A., D.W. Brankow, and C. Heiderberger. 1973a. Establishment and characterization of a cloned line of $\mathrm{C} 3 \mathrm{H}$ mouse embryo cells sensitive to postconfluence inhibition of cell division. Cancer Res. 33: 3231-3238.

Reznikoff, C.A., J.S. Bertram, D.W. Brankow, and C. Heiderberger. 1973b. Quantitative and qualitative studies of chemical transformation of cloned $\mathrm{C} 3 \mathrm{H}$ mouse embryo cells sensitive to postconfluence inhibition of cell division. Cancer Res. 33: 3239-3249.

Richardson, B.J., A.B. Czuppon, and G.B. Sharman. 1971. Inheritance of glucose-6-phosphate dehydrogenase variation in kangaroos. Nat. New Biol. 230: 154-155.

Riley, D.E., T.K. Canfield, and S.M. Gartler. 1984. Chromatin structure of active and inactive human $\mathrm{X}$ chromosomes. $\mathrm{Nu}$ cleic Acids Res. 12: 1829-1845.

Riley, D.E., M.A. Goldman, and S.M. Gartler. 1986. Chromatin structure of active and inactive human X-linked phosphoglycerate kinase gene. Somat. Cell Mol. Genet. 12: 73-80.

Rotwein, P. and L.J. Hall. 1990. Evolution of insulin-like growth factor II: Characterization of the mouse IGF-II gene and identification of two pseudo-exons. DNA Cell Biol. 9: 725-735.

Sapienza, C. 1990. Sex-linked dosage-sensitive modifiers as imprinting genes. Development (Suppl.) 107-113.

. 1991. Genomic imprinting and carcinogenesis. Biochim. Biophys. Acta 1072: 51-61.

Sapienza, C., A.C. Peterson, J. Rossant, and R. Balling. 1987. Degree of methylation of transgenes is dependent on gamete of origin. Nature 328: 251-254.

Sapienza, C., J. Paquette, T.H. Tran, and A. Peterson, 1989. Epigenetic and genetic factors affect transgene methylation imprinting. Development 107: 165-168.

Sasaki,H., T. Hamada, T. Ueda, R. Seki, T. Higashinakagawa, and Y. Sakaki. 1991. Inherited type of alleleic methylation variations in a mouse chromosome region where an integrated transgene shows methylation imprinting. Development 111: 573-581.

Searle, A.G. and C.V. Beechey. 1990. Genomic imprinting on mouse chromosome 7. Genet. Res. 56: 237-244.

Searle, A.G., J. Peters, M.F. Lyon, J.G. Hall, E.P. Evans, J.H. Edwards, and V.J. Buckle. 1989. Chromosome map of man and mouse. IV. Ann. Hum. Genet. 53: 89-140.

Sharman, G.B. 1971. Late replication in the paternally derived X chromosome of female kangaroo. Nature 230: 231-232.

Singer-Sam, J., M. Grant, J.M. LeBon, K. Okuyama, V. Chapman, M. Monk, and A.D. Riggs. 1990. Use of a Hpall-polymerase chain reaction assay to study DNA methylation in the Pgk-1 CpG island of mouse embryos at the time of X-chromosome inactivation. Mol. Cell. Biol. 10: 4987-4989.

Singh, P.B., J.R. Miller, J. Pearce, R. Kothary, R.D. Burton, R. Paro, T.C. James, and S.J. Gaunt. 1991. A sequence motif found in a Drosophila heterochromatin protein is conserved in animals and plants. Nucleic Acids Res. 19: 789-794.

Solter, D. 1988. Differential imprinting and expression of maternal and paternal genomes. Annu. Rev. Genet. 22: 127146.

Spencer, C.A. and M. Groudine. 1990. Transcription elongation and eukaryotic gene regulation. Oncogene 5: 777-785.

Stauffer, J.K. and E. Ciejek-Baez. 1992. Autonomous activity of the alternate aldolase A muscle promoter is maintained by a sequestering mechanism. Nucleic Acids Res. 20: 327-336.

Stempien, M.M., N.M. Fong, L.B. Rall, and G.I. Bell. 1986. Sequence of a placental cDNA encoding the mouse insulinlike growth factor II precursor. DNA 5: 357-361.

Surani, M.A.H. 1986. Evidences and consequences of differences between maternal and paternal genomes during embryogenesis in the mouse. In Experimental approaches to mammalian embryonic development (ed. J. Rossant and R.A. Pederson), pp. 401-436. Cambridge University Press, Cambridge, UK.

Surani, M.A., S.C. Barton, S.K. Howlett, and M.L. Norris. 1988. Influences of chromosomal determinants on development of androgenetic and parthenogenetic cells. Development 103: $171-178$.

Surani, M.A., R. Kothary, N.D. Allen, P.B. Singh, R. Fundele, A.C. Ferguson-Smith, and S.C. Barton. 1990. Genomic imprinting and development in the mouse. Development (Suppl.) 89-98.

Swain, J.L., T.A. Stewart, and P. Leder. 1987. Parental legacy determines methylation and expression of an autosomal transgene: A molecular mechanism for parental imprinting. Cell 50: 719-727.

Takagi, N. and M. Sasaki. 1975. Preferential inactivation of the paternally derived $\mathrm{X}$ chromosome in the extraembryonic membranes in the mouse. Nature 256: 640-642.

Tartof, K.D. and M. Bremer. 1990. Mechanisms for the construction and developmental control of heterochromatin formation and imprinted chromosome domains. Development (Suppl.) 35-45.

Taylor, E.R., E.A.P. Seleiro, and P.M. Brickell. 1991. Identification of antisense transcripts of the chicken insulin-like growth factor-II gene. $J$. Mol. Endocrinol. 7: 145-154.

Toniolo, D., M. D'Urso, G. Martini, M. Persico, V. Tufano, G. Battistuzzi, and L. Luzatto. 1984. Specific methylation pattern at the $3^{\prime}$ end of the human housekeeping gene for glucose-6-phosphate dehydrogenase. EMBO J. 3: 1987-1995.

Vacher, J. and S.M. Tilghman. 1990. Dominant negative regulation of the mouse $\alpha$-fetoprotein gene in adult liver. Science 250: 1732-1735.

West, J.D., W.I. Frels, V.M. Chapman, and V.E. Papaioannou. 
Sasaki et al.

1977. Preferential expression of the maternally derived X chromosome in the mouse yolk sac. Cell 12: 873-882.

Wolf, S.F. and B.R. Migeon. 1985. Clusters of CpG dinucleotides implicated by nuclease hypersensitivity as control elements of housekeeping genes. Nature 314: 467-469.

Wolf, S.F., S. Dintzis, D. Toniol, G. Persico, K.D. Lunnen, J. Axelman, and B.R. Migeon. 1984. Complete concordance between glucose- 6 phosphate dehydrogenase activity and hypomethylation of 3' CpG clusters: Implications for $\mathrm{X}$ chromosome dosage compensation. Nucleic Acids Res. 12: 9333-9348.

Wu, C. 1989. Analysis of hypersensitive sites in chromatin. Methods Enzymol. 170: 269-289.

Yang, T.P. and C.T. Caskey. 1987. Nuclease sensitivity of the mouse HPRT gene promoter region: Differential sensitivity on the active and inactive X chromosomes. Mol. Cell. Biol. 7: 2994-2998.

Yen, P.H., P. Patel, A.C. Chinault, T. Mohandas, and L.J. Shapiro. 1984. Differential methylation of hypoxanthine phosphoribosyltransferase gene on active and inactive human X chromosomes. Proc. Natl. Acad. Sci. 81: 1759-1763.

Yoo-Warren, H., V. Pachnis, R.S. Ingram, and S.M. Tilghman. 1988. Two regulatory domains flank the mouse $\mathrm{Hl} 9$ gene. Mol. Cell. Biol. 8: 4707-4715. 


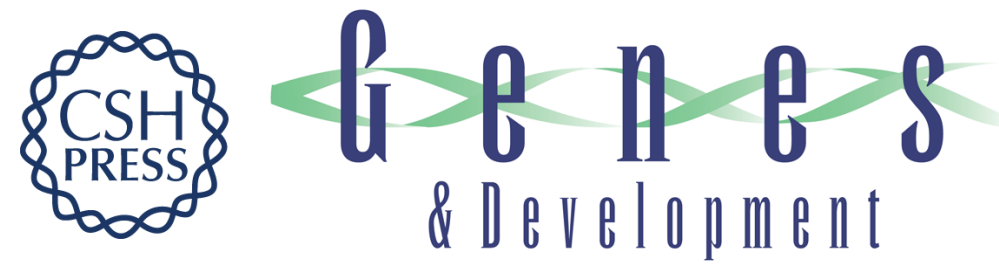

\section{Parental imprinting: potentially active chromatin of the repressed maternal allele of the mouse insulin-like growth factor II (Igf2) gene.}

H Sasaki, P A Jones, J R Chaillet, et al.

Genes Dev. 1992, 6:

Access the most recent version at doi:10.1101/gad.6.10.1843

References This article cites 75 articles, 22 of which can be accessed free at:

http://genesdev.cshlp.org/content/6/10/1843.full.html\#ref-list-1

License

Email Alerting

Service

Receive free email alerts when new articles cite this article - sign up in the box at the top right corner of the article or click here.

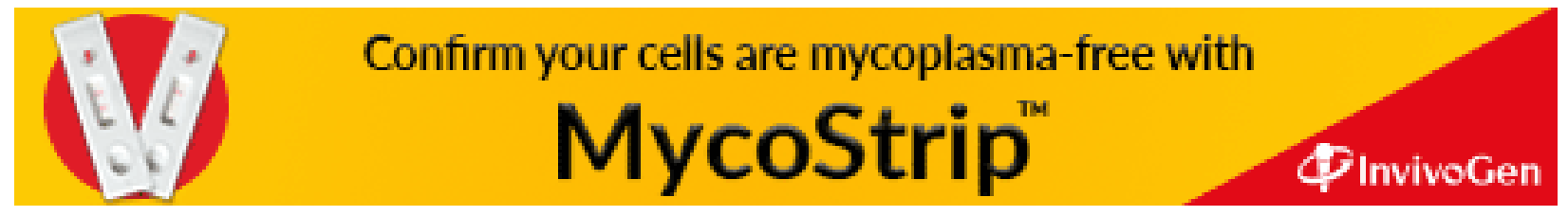

